\title{
IgG4-related disease (IgG4-RD) in developmental age — diannostic and therapeutic problems
}

\section{ABSTRACT}

The IgG4-related disease (IgG4-RD) is a type of a Hypergammaglobulinemia with elevated class IgG4 of unknown aetiology. It is still rarely diagnosed due to lack of clear diagnostic criteria and uncertain ethiopathogenesis. The most characteristic features are lymphocytes and plasmocytes IgG4+ inflammatory infiltrations located in various tissues and organs with elevated blood serum levels of IgG4. It mostly affects lacrimal glands, salivary glands and pancreas, therefore the clinical picture may suggest the Sjögren syndrome. The inflammatory process that is chronic and reccurent finally leads to fibrosis and sclerosis of affected tissues and organs function deterioration.
The clinical picture of lgG4-RD is highly variable depending on which organs are affected. Most patients may be treated with glycocortykosteroids, however some of them develop recrudescence.

The article consists of case report of the 11-yearsold boy diagnosed with the IgG4-RD. The authors showed the diagnostic and therapeutic process paying particular attention to avoid diagnostic traps. They discussed the diagnostic criteria and differential diagnostics. The IgG4-RD among pediatric population is still barely known by paediatricians. Only isolated cases are described so far.

Forum Reumatol. 2019, tom 5, nr 3: 149-153

Key words: IgG4-related disease (IgG4-RD) in children; diagnosis and therapy

\section{CASE REPORT}

A 10.5-year-old boy was admitted to the 2nd Clinical Department of Older Children with subunits of Neurology and Rheumatology of the St. Louis Provincial Specialist Children's Hospital in Cracow to diagnose recurrent fevers and low-grade fevers accompanied by bilateral enlargement of submandibular salivary glands and cervical lymph nodes. The boy reported discomfort, weakness and pain in the hip, knee and ankle joints. These symptoms had continued for two months. Initially, outpatient diagnosis indicated lymphadenitis, then scarlet fever. Antibiotic therapy was used in treatment, both on an outpatient basis and during the boy's hospitalisation in the District Hospital. Despite long-term antibiotic therapy, low-grade fevers as well as enlargement of cervical lymph nodes and submandibular salivary glands persisted. High inflammatory markers, elevated levels of $\operatorname{IgA}, \operatorname{IgG}$ and IgE class immunoglobulins, normal IgM class levels and significant eosinophilia in peripheral blood smear $(19 \%)$ were observed. As the administered treatment brought no improvement and the boy felt increasingly worse, with significant weakness and increasing joint pain, it was decided that further diagnosis was needed, and the boy was transferred to this centre.

At the time of admission to the department, the boy's general condition was moderate; he was pale, apathetic, with a hyposthenic body habitus. Pale skin was noted during the physical examination; notable observations included enlarged submandibular salivary glands on both sides, hard and tender in palpation, not moving in relation to the ground, with a diame-
Adres do korespondencji: dr hab. n med. Zbigniew Żuber, prof. nadzw. Clinical Ward for Older Children with Neurology and Rheumatology subdivision at the St. Louis Regional Specialised Children's Hospital ul. Strzelecka 2

31-503 Kraków tel.: +48126198630 fax: + 48126198681 e-mail: zbyszekzuber@interia.pl 

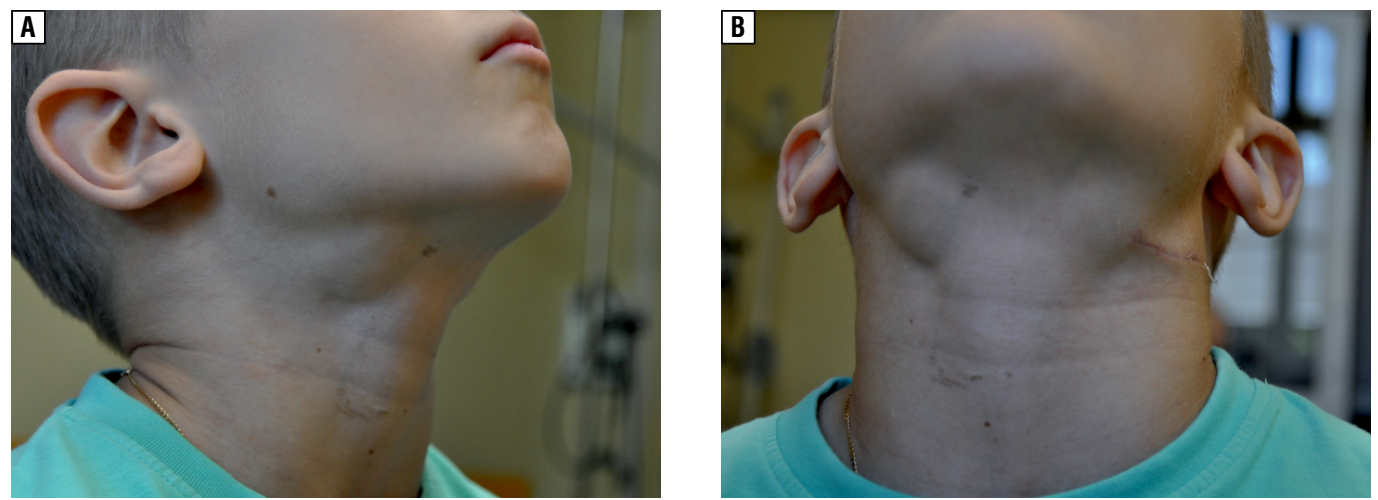

Figure 1A, B. Both sides enlarged cervical and submandibular lymph nodes

ter of approx. $4 \mathrm{~cm}$ on the right side and $3 \mathrm{~cm}$ on the left side, as well as bilaterally enlarged cervical and submandibular lymph nodes (Fig. 1) Locomotor system examination indicated limited internal rotation in hip joints; other joints did not show signs of inflammation.Performed laboratory tests showed elevated ESR of $42 \mathrm{~mm} / \mathrm{h}$, with normal CRP (10 mg/l), complete blood count indicated thrombocythemia (466 thousand/uL), smear showed eosinophilia (15.5\%), protein electrophoresis revealed elevated levels of alpha-2 and gamma globulins, elevated levels of $\mathrm{IgG}$ and $\operatorname{IgA}$, high concentration of $\mathrm{IgG} 4-1.889 \mathrm{~g} / \mathrm{L}(\mathrm{n}-0.08-1.40)$ and significantly elevated $\operatorname{IgE}$ of $4397 \mathrm{~g} / \mathrm{L}$ ( 0-200). TNF-alpha concentration was determined to be $335.26 \mathrm{pg} / \mathrm{mL}$ ( $\mathrm{n} 750-1500 \mathrm{pg} / \mathrm{mL}$ ), while IL-6 concentration was found to be 19851.2 pg/mL (n 1000-5000 pq/mL).

Immunological tests normal (ANA, ANCA, immunoblot profile anti-PR3 and anti-MPO). No IgM class rheumatoid factor (RF) or HLA-B27 antigen was found. In serological tests, marked anti-Mycoplasma pneumoniae, Chlamydia trachomatis, Borrelia, Toxoplasma, Toxocara antibodies were negative. Only IgG class antibodies for Yersinia Enterocolitica were found. Chest X-ray, ECG, abdominal ultrasound were normal. ECHO examination of the heart indicated a trace, insignificant tricuspid regurgitation.

In order to exclude hematopoietic proliferation, a bone marrow biopsy was performed; a normal myelogram was obtained. Ultrasound examination of the locomotor system confirmed bilateral hip arthritis. The Schirmer's test ruled out symptoms of dryness in the visual system.

Diagnostics of enlarged salivary glands and cervical lymph nodes included imaging tests: ultrasound and tomography of the neck and chest (HRCT), which revealed nonspecific lesions in the submandibular salivary glands (multinodular pattern), which may suggest inflammatory lesions, granulomatous diseases or autoimmune diseases. HRCT of the lungs showed bilateral, peripheral and subpulmonary, nodules without clear borders, including in the posterior paraspinal section of segment 10 of the lung, in segment 6 of the left lung by the oblique interlobar fissure and peripherally in segment 5 of the left lung at the anterior axillary line. The procedure also showed small stranded foci of parenchymal consolidation in the lower lobe of the left lung as a pattern of post-inflammatory lesions or fibrosis.

As IgG4-RD was suspected, histopathological examination of the affected organ - the submandibular salivary gland — was performed; result of this examination was interpreted in the context of the clinical picture. The histopathological material was subjected to two independent opinions of anatomical pathologists. The non-specific histopathological picture did not meet the diagnostic criteria for vasculitis group diseases (including Churg-Strauss) or Kimura's disease. The fragment of the salivary gland was characterized by slight fibrosis and significant inflammatory infiltration of lymphocytes and plasma cells. Number of IgG+ plasma cells: 36 per HPF, number of IgG4+ plasma cells: 15 . Although the absolute number of IgG+ plasma cells was lower than the number considered diagnostic, over $40 \%$ of plasma cells were of the IgG4+ subclass, which, in the context of clinical data, enabled diagnosis of the IgG4-related disease (IgG4-RD).

Ultimately, on the basis of overall clinical symptoms, result of histopathological examination of the submandibular salivary gland, as well as results of laboratory and immunological tests, the IgG4-related disease was diagnosed. 
The first line of treatment included a prednisone preparation at a dose of $0.4 \mathrm{mg} / \mathrm{kg}$; the preparation was well-tolerated.

During subsequent follow-up hospitalisations, the patient's clinical condition showed significant improvement, with a gradual decrease in the volume of peripheral lymph nodes and submandibular salivary glands, subsiding of hip arthritis, reduction in IgE and G4 immunoglobulin levels in the serum and a slight regression of lesions within the lungs found via HRCT. During subsequent follow-up visits, due to the persistence of inflammation within the right hip joint, Methotrexate, a DMARD, was included in treatment. Further observation showed that clinical symptoms and inflammatory lesions (checked via ultrasound examination) within hip joints subsided completely. Follow-up HRCT of the lungs was stationary. Subsequent follow-up examinations showed further decrease in $\mathrm{IgE}$ and $\mathrm{IgG} 4$ levels, with a tendency to normalise, which allowed for a gradual reduction and ultimate discontinuation of glucocorticosteroid treatment. The boy remains under constant rheumatic care. No relapse has been observed for 12 months.

\section{DISCUSSION}

Recurrent fevers, lymph node and salivary gland enlargement and joint pain are non-specific symptoms which may suggest multiple more common developmental age diseases, including infectious diseases, oncological diseases and rheumatic diseases other than IgG4-related. Non-specific and varied symptoms of IgG4-RD, which depend on the affected organ, make proper diagnosis difficult (Table 1,2). Differential diagnosis should include Sjögren's syndrome, other organ-specific autoimmune diseases, oncological diseases, sarcoidosis, Castleman's disease and systemic vasculitis. It should also be mentioned that the increased levels of IgG4 immunoglobulin can be found in many other chronic inflammatory diseases. [1-4].

IgG4-RD diseases are rare diseases of chronic and recurrent nature, in the course of which inflammatory infiltrations are formed in the affected tissues and organs, composed mainly of lymphocytes and IgG4-positive plasmacytes. In most cases, it is accompanied by an increase in levels of the IgG4 immunoglobulin subclass in the serum. The above-mentioned process leads to varying degrees of fibrosis and an impairment of the function of the affected organs over time. According to the data from literature, the lesions can affect any organ or tissue, but most often they include the gastrointestinal organs, pancreas, liver and bile ducts, salivary glands, as well as orbits and lymph nodes. The disease less frequently occurs in the mediastinum, retroperitoneal space, soft tissues, central nervous system, thyroid gland, respiratory tracts, kidneys, mammary gland, prostate gland and skin. $[1,2,5,6]$ The

Table 1. Guidelines for the diagnosis of IgG4-related disease (Research Program for Intractable Disease Ministry of Health, Labor and Welfare Japan G4 team) [13]

\begin{tabular}{|c|c|}
\hline Highly suggestive lesions of the lgG4-related disease & $\begin{array}{l}\text { Highly suggestive of the IgG4-related disease laboratory } \\
\text { parameters }\end{array}$ \\
\hline $\begin{array}{l}\text { 1. Symmetrical swelling of the lacrimal, parotid and sub- } \\
\text { mandibular glands } \\
\text { 2. Autoimmune pancreatitis } \\
\text { 3. Inflammatory pseudo-tumour in the affected organ } \\
\text { 4. Retroperitoneal fibrosis } \\
\text { 5. Suspicion of Castleman's disease }\end{array}$ & $\begin{array}{l}\text { 1. Increased serum IgG4 level ( } \geq 135 \mathrm{mg} / \mathrm{dl}) \\
\text { 2. Tissue biopsy, } \lg \mathrm{G} 4+/ \lg \mathrm{G}+\text { plasma cells ratio of }>40 \%\end{array}$ \\
\hline Clinical signs suggesting the IgG4-related disease & $\begin{array}{l}\text { Lesions suggesting the IgG4-related disease } \\
\text { — laboratory parameters }\end{array}$ \\
\hline $\begin{array}{l}\text { 1. Swelling of at least one of the following glands: lacrimal, } \\
\text { parotid, mandibular } \\
\text { 2. Pseudo-orbital tumour } \\
\text { 3. Prostate inflammation } \\
\text { 4. Hypertrophic meningitis (mainly dura mater) } \\
\text { 5. Interstitial pneumonia } \\
\text { 6. Thyroiditis or hypothyroidism } \\
\text { 7. Nephritis } \\
\text { 8. Hypopituitarism } \\
\text { 9. Inflammatory aortic aneurysm }\end{array}$ & $\begin{array}{l}\text { 1. Hypergammaglobulinemia of unknown origin } \\
\text { 2. Hypocomplementemia or presence of immune complexes } \\
\text { 3. Increase in serum IgE levels or eosinophilia } \\
\text { 4. Swelling of the lymph nodes diagnosed in a gallium CT } \\
\text { scan or fluoro-D-glucose positron-emission tomography } \\
\text { (FDG-PET) }\end{array}$ \\
\hline
\end{tabular}


Table 2. Criteria for diagnosing IgG4-related diseases according to Umehar et al. [9]

\begin{tabular}{|c|c|}
\hline 1. & Characteris \\
\hline 2. & Increased \\
\hline 3. & $\begin{array}{l}\text { Lesions in } \\
\text { - infiltration } \\
\text { - infiltration } \\
\text { scope's F }\end{array}$ \\
\hline Diagnosis & \\
\hline Definite & $1+2+3$ \\
\hline Probable & $1+3$ \\
\hline Possible & $1+2$ \\
\hline
\end{tabular}

appearance of disease symptoms is usually associated with extensive involvement of a given organ $[1,6,7]$. Most often, the onset of the disease is subacute, with no detectable systemic symptoms, and the diagnosis is made randomly during diagnostic tests.

The pathogenesis of IgG4-related diseases is still not fully known. It is currently believed that many factors are involved in the development of the disease. Immunoglobulin G4 as well as autoimmune, allergic and infectious factors are taken into account. IgG4 is a subclass of immunoglobulins that occurs with the lowest percentage in serum and has a unique structure and properties. It shows anti-inflammatory properties. It is also dependent on type 2 helper lymphocytes (Th2), which are involved in allergisation processes. A physiological IgG4-related response may be initiated by repeated exposure to antigen. Therefore, it is assumed that autoimmune and infectious factors may be the triggering factors in $\mathrm{IgG}_{4}$ -related diseases. However, it is still unclear whether the IgG4 immunoglobulin is characterised with pathogenicity. In response to Th2-related cytokines, such as interleukins (ILs) $-4,-5,-10$ and -13 , and the transforming growth factor $\beta$ (TGF- $\beta$ ), IgG4 and IgE levels increase as well as eosinophilia and progression of fibrosis occur $[1,5,6,8]$. According to literature reports, studies are being conducted on the genetic background of IgG4-related disease and the role of intestinal microbiome in the aetiology of this group of diseases.

Laboratory diagnosis requires the determination of serum IgG4 concentrations and laboratory parameters typical of dysfunction of a given organ. Medical imaging should include radiological, ultrasound and tomographic examinations and MRI. It is also necessary to perform histopathological evaluation of the biopsy specimen of the affected organ or tissue.
The final diagnosis of IgG4-related disease is based on the coexistence of characteristic lesions in histopathological picture (infiltrations from lymphocytes and IgG4-positive plasma cells), increased serum IgG4 concentration ( $\geq$ $135 \mathrm{mg} / \mathrm{dL}$ ) and the presence of organegaly with progressive organ dysfunction $[1,6,7,10]$.

In 2012, Umehara et al. developed diagnostic criteria for IgG4-related diseases listed in Table 2.

The prevalence of new cases is estimated at 2.63-10.2 cases per million people. The disease is more common in males than females (5:1), the average age: 65 years. The disease may also manifest at a younger age, and even in children [10-13]. The prevalence of the disease in the paediatric population is still unknown. In 2016, Karim et al. [13] published data on the analysis of the literature of the published IgG4-RD reports in children. 740 articles concerning this disease were analysed, whereas only 22 of them concerned the paediatric population, where 25 cases of IgG4-RD were described. The average age of children was 13 years; girls dominated (64\%). The orbits constituted $44 \%$ of affected organs, autoimmune thyroiditis was diagnosed in $12 \%$, while pneumonia, cholangitis and lymphatic system involvement were less frequent. In most cases, described in the literature, the diagnosis was made after the histopathological examination of an organ biopsy.

There have been no clear official guidelines and schemes for the treatment of IgG4-related diseases so far, and steroid therapy is usually used in first-line therapy. There is still no consensus on the treatment duration and the dose of GCS used. As a rule, a good response to treatment (about 80\%) was obtained. There were also described treatment attempts with LMPCh (DMARDs): mycophenolate mofetil, azathioprine and metho- 
trexate, with limited success. The best results were obtained during the anticytokine treatment with Rituximab, which was $100 \%$ effective in 4 patients, but these are only casuistic cases.

\section{SUMMARY}

Due to the still limited experience in the diagnosis of IgG4-related diseases in children and the lack of official treatment guidelines, the diagnostic and therapeutic process still remains a challenge and the prognosis of progress and remission of the disease still remains uncertain. The case of the described patient in the developmental age leads to the diagnosis of infectious aetiology of the reported symp- toms in the first place and the inclusion of antibiotic therapy.

Non-specific symptoms usually delay the proper diagnosis. Lack of effectiveness of routine antibiotic therapy requires the revision of the primary diagnosis and the extension of differential diagnosis. The key point in the diagnostic process seems to be the determination of serum $\mathrm{IgG} 4$ subclass concentration of immunoglobulins as well as the evaluation of the function parameters of affected organs, imaging and functional tests and reliable histopathological evaluation of the affected tissues. The reliable diagnosis of IgG4-RD requires a histopathological examination of the affected organ or tissue, the outcome of which should be interpreted in a clinical context.
1. Grygiel-Górniak B, Puszczewicz M. IgG4-related diseases a new look in rheumatology. Reumatologia/Rheumatology. 2013; 4: 284-292, doi: 10.5114/reum.2013.37252.

2. Masiak A, Zdrojewski Z. IgG4-related disease and systemic vasculitis - is there any connection? Reumatologia/Rheumatology. 2014; 6: 384-387, doi: 10.5114/reum.2014.47232.

3. Masiak A, Zdrojewski Z. Różne oblicza choroby lgG4-zależnej. Forum Reumatol. 2016; 2(1): 21-31.

4. Stone JH, Chan JKC, Deshpande V, et al. IgG4-Related Disease. Int J Rheumatol. 2013; 2013: 532612, doi: 10.1155/2013/532612, indexed in Pubmed: 23401693.

5. Pieringer $\mathrm{H}$, Parzer I, Wöhrer A, et al. IgG4- related disease: an orphan disease with many faces. Orphanet $J$ Rare Dis. 2014; 9: 110, doi: 10.1186/s13023-014-0110-z, indexed in Pubmed: 25026959.

6. Umehara $\mathrm{H}$, Okazaki $\mathrm{K}$, Masaki $\mathrm{Y}$, et al. Comprehensive diagnostic criteria for IgG4-related disease (IgG4-RD), 2011. Modern Rheumatology. 2012; 22(1): 21-30, doi: 10.1007/s10165-011-0571-z.

7. Umehara H, Okazaki K, Masaki Y, et al. Research Program for Intractable Disease by Ministry of Health, Labor and Welfare (MHLW) Japan G4 team. A novel clinical entity, IgG4-related disease (IgG4RD): general concept and details. Mod Rheumatol. 2012; 22(1): 1-14, doi: 10.1007/s10165-0110508-6, indexed in Pubmed: 21881964.
8. Masaki $\mathrm{Y}$, Kurose N, Umehara H. IgG4-related disease: a novel lymphoproliferative disorder discovered and established in Japan in the 21st century. J Clin Exp Hematop. 2011; 51 (1): 13-20, indexed in Pubmed: 21628856.

9. Okazaki K, Umehara H. Are Classification Criteria for IgG4-RD Now Possible? The Concept of IgG4-Related Disease and Proposal of Comprehensive Diagnostic Criteria in Japan. Int J Rheumatol. 2012; 2012: 357071, doi: 10.1155/2012/357071, indexed in Pubmed: 22690221.

10. Corujeira S, Ferraz C, Nunes T, et al. Severe IgG4-Related Disease in a Young Child: A Diagnosis Challenge. Case Rep Pediatr. 2015; 2015: 140753, doi: 10.1155/2015/140753, indexed in Pubmed: 25705537.

11. Mannion $M$, Cron $R Q$. Successful treatment of pediatric IgG4 related systemic disease with mycophenolate mofetil: case report and a review of the pediatric autoimmune pancreatitis literature. Pediatr Rheumatol Online J. 2011; 9(1): 1, doi: 10.1186/1546-0096-9-1, indexed in Pubmed: 21205323.

12. Bolia R, Chong SY, Coleman L, et al. Autoimmune Pancreatitis and IgG4 Related Disease in Three Children. ACG Case Rep J. 2016; 3(4): e115, doi: 10.14309/cri.2016.88, indexed in Pubmed: 27622194.

13. Karim F, Loeffen J, Bramer W, et al. IgG4-related disease: a systematic review of this unrecognized disease in pediatrics. Pediatr Rheumatol Online J. 2016; 14(1): 18, doi: 10.1186/s12969016-0079-3, indexed in Pubmed: 27012661. 


\section{$\mathbf{V M}$ \\ VIA MEDICA \\ www.fr.viamedica.pl}

Justyna Orlicka, Dorota Turowska-Heydel, Zbigniew Żuber

Oddział Kliniczny Dzieci Starszych z pododdziałami Neurologii i Reumatologii, Szpital Dziecięcy św. Ludwika 31-503 Kraków ul. Strzelecka 2

\title{
Chorobala IgG4-zalezina (IIGG-RD) w wieku rozwojowym, problemy diagnostyczne i terapeutyczzne
}

\author{
Artykuł jest tłumaczeniem pracy: Orlicka J., Turowska-Heydel D., Żuber Z., IgG4-related disease (IgG4-RD) in developmen- \\ tal age — diagnostic and therapeutic problems. Forum Reumatol. 2019 tom 5, nr 3: 149-153. \\ Należy cytować wersję pierwotną. \\ Piśmiennictwo znajduje się na stronie 153.
}

\section{STRESZCZENIE}

Choroba IgG4-zależna (IgD4-RD) należy do hiper IgG4 gammaglobulinemii o wciąż nie do końca poznanej etiologii, jest chorobą rzadko rozpoznawaną. Brak jednoznacznych kryteriów diagnostycznych, nie w pełni poznana etiopatogeneza powodują znaczne trudności diagnostyczne. Charakterystyczną cechą tej choroby to powstające w tkankach i narządach nacieki zapalne złożone z limfocytów i plazmocytów lgG4+ z towarzyszącym wzrostem stężenia podklasy immunoglobulin lgG4 w surowicy krwi. Najczęściej zmiany chorobowe obejmują gruczoły łzowe, ślinowe, trzustkę, stąd obraz kliniczny może sugerować zespół Sjögrena. Przewlekły i nawrotowy proces zapalny prowadzi z czasem do włóknienia i stwardnienia zajętych narządów oraz zaburzeń ich funkcji. Obraz kliniczny IgD4-RD jest bardzo zróżnicowany w zależności od zajętych narządów. Glikokortykosteroidy są skuteczne w leczeniu większości chorych, w części przypadków obserwowane są nawroty choroby.

W artykule zawarto opis przebiegu choroby u 11-letniego chłopca, u którego zdiagnozowano lgG4-RD. Autorzy przedstawili przebieg procesu diagnostycznoterapeutycznego, ze zwróceniem szczególnej uwagi na możliwe pułapki diagnostyczne, omówiono kryteria rozpoznania oraz diagnostykę różnicową. Choroba IgG4zależna u dzieci jest mało znaną jednostką chorobową wśród pediatrów, dotychczas opisano jedynie pojedyncze przypadki tego zespołu chorobowego.

Forum Reumatol. 2019, tom 5, nr 3: 154-158

Słowa kluczowe: choroba IgG4-zależna (IgG4-RD) u dzieci; diagnostyka; terapia
Adres do korespondencji: dr hab. $n$ med. Zbigniew Żuber, prof. nadzw. Oddział Kliniczny Dzieci Starszych

z pododdziałami Neurologii i Reumatologii, Szpital Dziecięcy św. Ludwika ul. Strzelecka 2 31-503 Kraków

tel.: +48126198630

faks: + 48126198681 e-mail: zbyszekzuber@interia.pl

\section{OPIS PRZYPADKU}

Chłopiec 10,5-letni został przyjęty na II Oddział Kliniczny Dzieci Starszych z pododdziałem Reumatologii i Neurologii Wojewódzkiego Specjalistycznego Szpitala Dziecięcego im. św. Ludwika w Krakowie do diagnostyki nawracających gorączek, stanów podgorączkowych $\mathrm{z}$ towarzyszącym obustronnym powiększeniem ślinianek podżuchwowych oraz węzłów chłonnych regionu szyi. Chłopiec zgłaszał gorsze samopoczucie, osłabienie oraz dolegliwości bólowe okolicy stawów biodrowych, kolanowych i skokowych. Objawy te utrzymywały się od dwóch miesięcy. Początkowo, ambulatoryjnie rozpoznawano zapalenie węzłów chłonnych, następnie szkarlatynę. W leczeniu zastosowano antybiotykoterapię zarówno w warunkach ambulatoryjnych, jak i w trakcie hospitalizacji chłopca w Szpitalu Rejonowym. Pomimo zastosowania długotrwałej antybiotykoterapii nadal utrzymywały się stany podgorączkowe, powiększenie węzłów chłonnych szyjnych oraz ślinianek podżuchwowych. Stwierdzano wysokie wskaźniki stanu zapalnego, podwyższone stężenie immunoglobulin w klasie $\operatorname{IgA}$, IgG i IgE, w klasie IgM stężenie było w normie, oraz znaczną eozynofilię w rozmazie krwi obwodowej (19\%). Brak poprawy po zastosowanym leczeniu, coraz gorsze samopoczucie chłopca, znaczne osłabienie oraz nasilające się dolegliwości bólowe w zakresie 

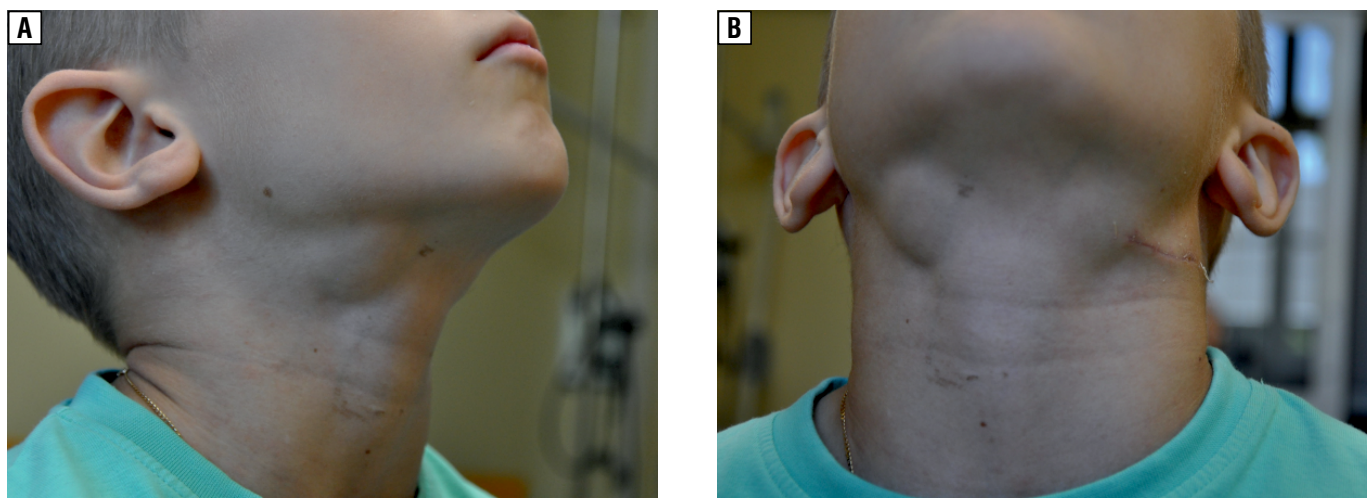

Rycina 1A, B. Obustronnie powiększone węzły chłonne szyjne i podżuchwowe

stawów skłoniły do podjęcia decyzji o dalszej diagnostyce, przesłano chłopca do ośrodka autorów pracy.

W chwili przyjęcia na Oddział chłopiec był w stanie ogólnym średnim, blady, apatyczny, budowa ciała hiposteniczna. W badaniu fizykalnym skóra blada, zwracały uwagę obustronnie powiększone ślinianki podżuchwowe, twarde i tkliwe w badaniu palpacyjnym, nieprzemieszczające się względem podłoża, o średnicy około $4 \mathrm{~cm}$ po stronie prawej i $3 \mathrm{~cm}$ po lewej oraz obustronnie powiększone węzły chłonne szyjne i podżuchwowe (ryc. 1). W badaniu narządu ruchu stwierdzono ograniczenie rotacji wewnętrznej w stawach biodrowych, pozostałe stawy bez cech stanu zapalnego. W wykonanych badaniach laboratoryjnych stwierdzono podwyższone OB $42 \mathrm{~mm} / \mathrm{h}$, przy prawidłowym CRP $(10 \mathrm{mg} / \mathrm{l})$, w morfologii nadpłytkowość (466 tys./ul) oraz eozynofilię w rozmazie $(15,5 \%)$, w elektroforezie białek podwyższone stężenie $\alpha_{2}$ i gammaglobulin, podwyższone stężenia IgG i IgA, wysokie stężenie IgG4 - 1,889 g/l (norma 0,08-1,40), znacznie podwyższone IgE — $4397 \mathrm{~g} / 1$ (norma 0-200). Oznaczono stężenie czynnika martwicy nowotworów $\alpha$ (TNF- $\alpha$, tumor necrosis factor alfa) - 335,26 pg/ml (norma 750 $1500 \mathrm{pq} / \mathrm{ml}$ ) oraz IL-6 19851,2 pg/ml (norma $1000-5000 \mathrm{pq} / \mathrm{ml})$.

Badania immunologiczne prawidłowe (ANA, ANCA, immunoblot profil anty-PR3 i anty MPO). Nie stwierdzono obecności czynnika reumatoidalnego (RF, rheumatoid factor) klasy IgM ani antygenu HLA B27. W badaniach serologicznych oznaczone przeciwciała przeciwko Mycoplazma pneumoniae, Chlamydia trachomatis, Borrelia, Toxoplasma, Toxoca$r a$ były ujemne. Stwierdzono jedynie obecność przeciwciał klasy IgG dla Yersinia Enterocolitica. Rentgen klatki piersiowej, EKG, USG jamy brzusznej były prawidłowe. $\mathrm{W}$ badaniu ECHO serca stwierdzono śladową nieistotną niedomykalność zastawki trójdzielnej. Celem wykluczenia rozrostu krwiotwórczego wykonano biopsję szpiku kostnego, uzyskując prawidłowy mielogram.

Badanie ultrasonograficzne narządu ruchu potwierdziło obustronne zapalenie stawów biodrowych. Testem Schirmera wykluczono objawy suchości w zakresie narządu wzroku.

W ramach diagnostyki powiększonych ślinianek i węzłów chłonnych szyjnych wykonano badania obrazowe: ultrasonograficzne oraz tomograficzne szyi, klatki piersiowej (HRCT), stwierdzając niecharakterystyczne zmiany w zakresie ślinianek podżuchwowych (obraz wieloguzkowy) mogące sugerować zmiany zapalne, choroby ziarniniakowe lub schorzenia z grupy chorób autoimmunologicznych. W HRCT płuc stwierdzono obustronnie, obwodowo i podopłucnowo nieostro odgraniczone guzki między innymi w części grzbietowo przykręgosłupowej segmentu 10 płuca, w segmencie 6 płuca lewego przy szczelinie międzypłatowej skośnej oraz obwodowo w segmencie 5 płuca lewego w linii pachowej przedniej. Badanie to wykazało również drobne pasmowate ogniska konsolidacji miąższowych w płacie dolnym płuca lewego jako obraz zmian pozapalnych lub zwłóknień.

Ze względu na podejrzenie choroby IgG4-zależnej (IgG4-RD, IgG4-related disease) wykonano badanie histopatologiczne zajętego narządu - ślinianki podżuchwowej, którego wynik interpretowany był w kontekście obrazu klinicznego. Materiał histopatologiczny poddano dwóm niezależnym opiniom patomorfologów. Niecharakterystyczny obraz histopatologiczny nie spełniał kryteriów rozpoznania choroby $\mathrm{z}$ grupy vasculitis ( $\mathrm{w}$ tym Churg-Strauss) ani choroby Kimury. Frag- 
ment ślinianki był $\mathrm{z}$ cechami nieznacznego włóknienia i z obfitym naciekiem zapalnym z limfocytów i plazmocytów. Liczba plazmocytów IgG+: 36 na DPW, liczba plazmocytów IgG4+: 15. Mimo że bezwzględna liczba plazmocytów IgG+ była mniejsza niż uznawana za diagnostyczną, to ponad $40 \%$ plazmocytów stanowiła podklasa IgG4+, co w kontekście danych klinicznych pozwoliło rozpoznać chorobę IgG4-zależną.

Ostatecznie na podstawie całokształtu objawów klinicznych, a także wyniku badania histopatologicznego ślinianki podżuchwowej, wyników badań laboratoryjnych i immunologicznych postawiono rozpoznanie choroby IgG4-zależnej. W pierwszej linii leczenia włączono preparat prednizonu w dawce w $0,4 \mathrm{mg} / \mathrm{kg}$, z dobrą tolerancją.

Podczas kolejnych kontrolnych hospitalizacji obserwowano znaczną poprawę stanu klinicznego pacjenta ze stopniowym zmniejszaniem objętości obwodowych węzłów chłonnych i ślinianek podżuchwowych, ustępowaniem stanu zapalnego stawów biodrowych, spadkiem stężenia IgE i immunoglobuliny G4 w surowicy oraz niewielką regresją zmian w obrębie płuc obserwowanych w HRCT. Podczas następnych wizyt kontrolnych z uwagi na utrzymywanie się stanu zapalnego w obrębie prawego stawu biodrowego do leczenia wprowadzono lek z grupy leków modyfikujących przebieg choroby (LMPCh [DMARDs, disease modifying antirheumatic drugs) — metotreksat.
W dalszej obserwacji stwierdzono całkowite ustąpienie objawów klinicznych oraz zmian zapalnych w badaniu USG w zakresie stawów biodrowych,. W kontrolnym badaniu HRCT płuc stwierdzano obraz stacjonarny. W trakcie kolejnych badań kontrolnych odnotowano dalszy spadek stężenia IgE i IgG4 z tendencją do normalizacji, co pozwoliło na stopniową redukcję i w konsekwencji na odstawienie leczenia GKS. Chłopiec pozostaje pod stałą opieką reumatologiczną. Przez okres 12 miesięcy nie obserwowano nawrotu choroby.

\section{DYSKUSJA}

Nawracające gorączki, powiększenie węzłów chłonnych i ślinianek, dolegliwości bólowe stawów, to niespecyficzne objawy mogące sugerować wiele częściej spotykanych chorób wieku rozwojowego, w tym chorób zakaźnych, chorób onkologicznych oraz innych niż IgG4-zależne schorzeń z kręgu chorób reumatologicznych. Niecharakterystyczne i różnorodne objawy chorób IgG4-RD uwarunkowane rodzajem zajętego narządu utrudniają postawienie właściwego rozpoznania (tab. 1, 2). W diagnostyce różnicowej należy uwzględnić chorobę Sjögrena, inne narządowo swoiste choroby autoimmunologiczne, schorzenia onkologiczne, sarkoidozę, chorobę Castlemana, układowe zapalenia naczyń. Należy także pamiętać, że zwiększone stężenie immunoglobuliny IgG4 może występować w wielu innych

Tabela 1. Zasady rozpoznawania chorób IgG4-zależnych (Research Program for Intractable Disease Ministry of Health, Labor and Welfare Japan G4 team) [13]

Zmiany bardzo sugerujące chorobę IgG4-zależną
1. Symetryczny obrzęk gruczołów łzowych, przyusznych
i podżuchwowych
2. Autoimmunologiczne zapalenie trzustki
3. Pseudoguz zapalny w zajętym narządzie
4. Włóknienie zaotrzewnowe
5. Podejrzenie choroby Castlemana

\section{Objawy kliniczne sugerujące chorobę IgG4-zależną}

1. Obrzęk przynajmniej jednego z gruczołów: łzowych, przyusznych, żuchwowych

2. Pseudoguz oczodołu

3. Zapalenie gruczołu krokowego

4. Przerostowe zapalenie opony mózgowo-rdzeniowej (głównie twardej)

5. Śródmiąższowe zapalenie płuc

6. Zapalenie lub niedoczynność tarczycy

7. Śródmiąższowe zapalenie nerek

8. Niedoczynność przysadki

9. Tętniak zapalny aorty
Parametry laboratoryjne bardzo sugerujące chorobę IgG4-zależną

1. Stężenie lgG4 w surowicy $>135 \mathrm{mg} / \mathrm{dl}$

2. Biopsja tkankowa stosunek $\lg \mathrm{G} 4+/ \lg \mathrm{G}+$ komórek plazmatycznych $>40 \%$

Zmiany sugerujące chorobę IgG4-zależną — parametry laboratoryjne

1. Hypergammaglobulinemia nieznanego pochodzenia 2. Hipokomplementemia lub obecność kompleksów immunologicznych

3. Wzrost stężenia IgE w surowicy lub eozynofilia

4. Obrzęk węztów chłonnych rozpoznanych w badaniu CT z galem lub fluoro-d-glukozowej emisyjnej tomografii pozytronowej (FDG-PET) 
Tabela 2. Kryteria rozpoznania chorób IgG4-zależnych według Umehara i wsp. [9]

1.

2.

3.
Charakterystyczne objawy zajęcia narządowego w postaci jego rozlanego lub guzkowego powiększenia lub nieprawidłowa funkcja narządu/-ów

Podwyższone stężenie lgG4 w surowicy ( $\geq 135 \mathrm{mg} / \mathrm{dl}$ )

Zmiany w badaniu histopatologicznym:

- naciek z limfocytów i komórek plazmatycznych oraz włóknienie

- naciek z komórek IgG4+: > 10 komórek IgG4 + w polu widzenia w mikroskopie o wysokiej rozdzielczości i stosunek komórek lgG4+/ $\lg \mathrm{G}>40 \%$

\section{Rozpoznanie choroby IgG4-zależnej}

Pewne (definite)

Prawdopodobne (probable)

Możliwe (possible)
$1+2+3$

$1+3$

$1+2$ chorobach przebiegających z przewlekłym procesem zapalnym [1-4].

Choroby IgG4-RD to rzadkie schorzenia o przewlekłym i nawrotowym charakterze, w przebiegu których w zajętych tkankach i narządach powstają nacieki zapalne złożone głównie z limfocytów i plazmocytów IgG4-dodatnich. W większości przypadków towarzyszy temu wzrost stężenia podklasy immunoglobulin IgG4 w surowicy. Powyższy proces z czasem w różnym stopniu prowadzi do włóknienia i upośledzenia funkcji zajętych narządów. Zgodnie $\mathrm{z}$ danymi $\mathrm{z}$ piśmiennictwa zmiany mogą dotyczyć każdego narządu i tkanki, jednak najczęściej obejmują narządy układu pokarmowego, trzustkę, przewód wątrobowo-żółciowy, gruczoły ślinowe, ale także oczodoły i węzły chłonne. Rzadziej choroba lokalizuje się w śródpiersiu, przestrzeni zaotrzewnowej, tkankach miękkich, ośrodkowym układzie nerwowym, tarczycy, drogach oddechowych, nerkach, gruczole sutkowym, prostacie i skórze $[1,2,5,6]$. Wystąpienie objawów chorobowych wiąże się zazwyczaj z rozległym zajęciem danego narządu [1, 6, 7]. Najczęściej początek choroby ma charakter podostry, bez uchwytnych objawów ogólnoustrojowych, a rozpoznanie ustalane jest przypadkowo w trakcie badań diagnostycznych.

Patogeneza chorób IgG4-zależnych w dalszym ciagu nie jest do końca poznana. Aktualnie uważa się, że w rozwoju choroby uczestniczy wiele czynników. Pod uwagę bierze się immunoglobulinę G4, czynniki autoimmunologiczne, alergiczne i zakaźne. Immunoglobulina G4 to podklasa immunoglobulin, która występuje w surowicy $\mathrm{w}$ najniższym odsetku i cechuje się unikalną strukturą i właściwościami. Wykazuje właściwości przeciwzapalne. Jest ona także zależna od limfocytów pomoc- niczych typu 2 (Th2), które biorą udział w procesach alergizacji. Fizjologiczna odpowiedź IgG4-zależna może być zainicjowana poprzez powtarzającą się ekspozycję na antygen. Stąd przypuszcza się, że czynnikami spustowymi w chorobach IgG4 zależnych mogą być czynniki autoimmunologiczne i zakaźne. Nadal jednak nie jest jasne czy immunoglobulina IgG4 ma właściwości chorobotwórcze. W odpowiedzi na działanie cytokin Th2-zależnych, takich jak interleukiny (IL) $-4,-5,-10 \mathrm{i}-13$ oraz transformujący czynnik wzrostu $\beta$ (TGF- $\beta$, transforming growth factor $\beta$ ), pojawia się eozynofilia, wzrasta stężenie IgG4 i IgE oraz następuje progresja włóknienia [1, 5, 6, 8]. Zgodnie $\mathrm{z}$ doniesieniami $\mathrm{z}$ literatury prowadzone są badania nad podłożem genetycznym choroby IgG4-zależnej oraz rolą mikrobiomu jelitowego w etiologii chorób z tej grupy.

W diagnostyce laboratoryjnej niezbędne jest oznaczenie stężenia IgG4 w surowicy oraz parametrów laboratoryjnych typowych dla dysfunkcji danego narządu. Diagnostyka obrazowa powinna obejmować badania radiologiczne, ultrasonograficzne i tomograficzne oraz MRI. Konieczna jest także ocena histopatologiczna materiału z biopsji zajętego narządu czy tkanki. Ostatecznego rozpoznanie choroby IgG4-zależnej ustala się na podstawie współwystępowania charakterystycznych zmian w obrazie histopatologicznym (nacieki z limfocytów i plazmocytów IgG4-dodatnich), zwiększenia stężenia IgG4 w surowicy ( $\geq 135 \mathrm{mg} / \mathrm{dl}$ ) oraz obecności organomegalii z postępującą dysfunkcją narządową $[1,6,7,10]$.

W tabeli 2 zestawiono opracowane przez Umehara i wsp. w 2012 roku kryteria diagnostyczne chorób z grupy IgG4-zależnych.

Częstość występowania nowych przypadków zachorowania ocenia się na 2,63-10,2 
przypadków na milion osób. Częściej chorują mężczyźni niż kobiety (5:1), średnia wieku (65 lat). Choroba może ujawnić się też w młodszym wieku, a nawet u dzieci [10-13]. Wciąż nieznana jest częstość występowania choroby w populacji dziecięcej. Karim i wsp. [13] w 2016 roku opublikowali dane dotyczące analizy piśmiennictwa opublikowanych raportów IgG4-RD u dzieci. Analizie poddano 740 artykułów dotyczących tej jednostki chorobowej, jedynie $22 \mathrm{z}$ nich dotyczyło populacji dziecięcej, gdzie opisano 25 przypadków IgG4-RD. Średnia wieku dzieci to 13 lat, dominowały dziewczęta $(64 \%)$. Zajęte narządy stanowiły w $44 \%$ oczodoły, w $12 \%$ rozpoznawano autoimmunologiczne zapalenie tarczycy, natomiast z mniejszą częstością obserwowano zajęcie płuc, zapalenie dróg żółciowych i zajęcie układu limfatycznego. W większości przypadków opisywanych w piśmiennictwie rozpoznanie postawiono po uzyskaniu wyniku badania histopatologicznego biopsji narządowej.

Jak dotąd nie powstały jednoznaczne oficjalne wytyczne i schematy leczenia chorób IgG4-zależnych, a w terapii pierwszego rzutu zazwyczaj stosuje się steroidoterapię. Wciąż brak jest konsensusu co do czasu trwania leczenia i dawki stosowanych glikokortykosteroidów, z reguły uzyskiwano dobrą odpowiedź na leczenie w około $80 \%$. Opisywano również próby leczenia z zastosowaniem LMPCh: mykofenolanu mofetilu, azatiopryny i metotreksatu, z ograniczonym powodzeniem. Najlepsze efekty uzyskano w trakcie leczenia antycytokinowego rytuksymabu, który u 4 pacjentów był w $100 \%$ efektywny, jednak są to tylko kazuistyczne przypadki.

\section{PODSUMOWANIE}

Z uwagi na wciąż niewielkie doświadczenie w rozpoznawaniu chorób z grupy IgG4-zależnych u dzieci, brak oficjalnych wytycznych dotyczących leczenia, proces diagnostyczno-terapeutyczny stanowi nadal wyzwanie, a rokowania co do postępu i remisji choroby w dalszym ciągu są niepewne. Przypadek opisanego pacjenta w wieku rozwojowym skłania w pierwszej kolejności do rozpoznania etiologii infekcyjnej zgłaszanych objawów i włączenia terapii antybiotykowej.

Niespecyficzne objawy z reguły opóźniają postawienie właściwego rozpoznania. Brak skuteczności rutynowo stosowanej antybiotykoterapii wymaga korekty pierwotnego rozpoznania i poszerzenia diagnostyki różnicowej. Kluczowym punktem w procesie diagnostycznym wydaje się być oznaczenie stężenia podklasy IgG4 immunoglobulin w surowicy, a także ocena parametrów funkcji zajętych narządów, badania obrazowe, czynnościowe oraz rzetelna ocena histopatologiczna zajętych tkanek. Ustalenie pewnego rozpoznania IgG4-RD wymaga wykonania badania histopatologicznego zajętego narządu lub tkanki, którego wynik powinien być interpretowany w kontekście klinicznym. 